\title{
Germination of jojoba (Simmondsia chinensis L) seeds under the influence of several conditions
}

\author{
Hassanein A. M. ${ }^{1}$, Galal E. ${ }^{2}$, Soltan D. ${ }^{1}$, Abed-Elsaboor K. ${ }^{2}$, Saad G. K. ${ }^{1}$, Gaboor G. M. ${ }^{1}$, El \\ Mogy N. S. ${ }^{3}$ \\ ${ }^{1}$ Central Laboratory of Genetic Engineering, Faculty of Science, Sohag University, 82524 Sohag, \\ Egypt. \\ ${ }^{2}$ Genetics Department, faculty of Agriculture, Sohag University, Sohag, Egypt. \\ ${ }^{3} \mathrm{Al}$ Obour Buildings 4, Salah Salem Road, Nasr City - Cairo, Egypt.
}

Rec. 20 Mar, 2012 Accpt. 2 May, 2012

\begin{abstract}
Our study indicates that jojoba is suitable plant for cultivation of the Egyptian marginal soils, in the desert area, where the seeds were germinated and grown in sandy soil of marginal fertility. To study the effect of $\mathrm{NaCl}$ and mannitol on seeds germination, jojoba seeds were placed on cotton layer flooded with solution containing different concentrations of them. Salinity stimulated seed germination, especially, when the seeds were subjected to relatively low concentration of $\mathrm{NaCl}(0.5-3 \mathrm{gm} / \mathrm{l})$. Increase the concentration of $\mathrm{NaCl}$ over $3 \mathrm{gm} / \mathrm{l}$ resulted in inhibition of seed germination as well as radicle growth. Application of 2 or $3 \mathrm{gm} / 1$ mannitol in germination medium improved the seed germination, vice versa was detected under progressive increase of mannitol in germination medium. Mannitol as same as $\mathrm{NaCl}$ delayed seed germination of jojoba plant. On the other hand, jojoba seeds can be germinated in low frequency under high concentration of mannitol, up to $100 \mathrm{gm} / \mathrm{l}$, when seeds were placed on three cotton layers just wetted by distilled water containing mannitol. Temperature may be the most critical factor during jojoba seed germination, therefore summer was the best season for seed germination; also, $30^{\circ} \mathrm{C}$ was the best temperature degree for seed germination and emergence of radical in the shortest time.
\end{abstract}

Key words: Desert cultivation, Jojoba, mannitol, sodium chloride, seed germination, stress.

\section{Introduction:}

Jojoba [Simmondsia chinensis (Link) Schneider] is a desert shrub which tolerates salinity and drought. The chromosome number of jojoba is $2 \mathrm{n}=52$ (Weiss, 1983). Its natural life span appears to be between 100 and 200 years. Jojoba seeds contain a liquid wax of economic importance in industry (machine lubricant) as well as in medicine, where it can be used in cosmetics and anticancer compounds. Jojoba was used as a medicine for cancer, stomach ache, kidney disorders, easing childbirth and in tending wounds (Weiss, 1983). Jojoba has attracted interest as a landscape plant; also it can be sued for soil conservation. The plant has a deep root system; therefore it can be used in highway and roadside plantings and hedges. It can also be used as a soil stabilizer in green belts around desert cities suffering from particulate air pollution. It is the only plant known that synthesizes liquid wax. The seeds contain about $50 \%$ of simple wax esters of mono-unsaturated fatty acids and alcohols.
Plantations are established by using seeds, seedlings, rooted cuttings, or plantlets produced from tissue culture (Roussos et al., 1999; Roussos et al., 2006; Mohasseb et al., 2009). The male plants outnumber the females when raised from seeds (Harsh et al., 1987). Jojoba plants obtained from seeds showed a high variability in most characteristics including yield because it is dioecious, and obligate cross-pollinated species (Gentry, 1958). Previous reports indicated that only a small proportion of the plant population (less than 1\%) originating from seeds of native plants has the potential to produce economically acceptable yields (Purcell and Purcell, 1988; Ramonet-Razon, 1988). Therefore, comprehensive selection and breeding program was conducted in many countries all over the world to obtain elite cultivars.

Salinity is considered one of the most important factor restrict the horticultural production, especially in soils of the arid and semi-arid regions on the earth. Few economical plant species can be grown

\footnotetext{
* Corresponding author:

Dr. Hassanein A.M.

$凶$ ahmed.hassanein@science.sohag.edu.eg
} 
successfully in saline soil. It is worth to mention that the total area of arable land is gradually decreasing due to the progressive salinization of the soil (Botti et al., 1998).

While jojoba is known as salt tolerant species (Jensen and Salisbury, 1988; Benzioni et al., 1992). salt damage can occur and differences in response among clones had been observed (Rasoolzadegan et al., 1980; Benzioni et al., 1992). indicating the possibility of developing clones with increased levels of salt resistance or tolerance. Elongation and thickening of stems (Bartolini et al., 1991). the total leaf area and leaf size (Bartolini et al., 1991). shoot and leaf expansion, number of leaves and flowers were reduced in response to increased levels of salinity (Rasoolzadegan et al., 1980; Benzioni et al., 1992). Increasing in leaf thickness was also reported when jojba plants were subjected to salt stress (Sa'nchez-Blanco et al., 1991).

Benzioni et al., 1999 reported that some clones exhibited excellent vegetative traits related to yield potential such as a high survival rate, rapid growth, extensive branching, high node density, high flower density, high percentage of fruit set, high seed weight, and high wax content in the seed. The clones also differed in their wax composition. Under Egyptian condition, jojoba maximally utilizes 50-70 liters of water weekly in summer and 10-30 liters in winter but when it irrigated by flooding, 1215 irrigation times per year is needed. Mature shrubs characterize by their strong ability to survive without irrigation for long time where they can survive for a whole year without watering. Jojoba can also tolerate up to 3,000 p.p.m. without any impact to the yield. Therefore, Jojoba is considered one of the most practical and scientific solutions for desert plantation in Egypt. In spite of its importance, very few studies aim to understand the effects of abiotic stresses on the development and yield of the jojoba. This article covers the research on jojoba ecophysiology, with emphasis on the effects of water and salt stress on seed germination.

\section{Material and Methods:}

Plant material: For the experiments, seeds were obtained from the Egyptian Natural Oil Co. S.A.E., Ismailia Farm, Salam Zone, Manayef, Ismailia, Cairo, Egypt. The farm is planted in Ismailia in 1991 and it is about $88,200^{\text {sq.m }}$ of jojoba plants, it was used for research and production.

Effect of soil type on seed germination: Thirty jojoba seeds were sown in plastic pots containing two $\mathrm{Kg}$ of soils composed from sand, soil or both according to the following table:

\begin{tabular}{|c|c|}
\hline \multicolumn{2}{|c|}{ Soil structure } \\
\hline Sandy soil & Clay soil \\
\hline $100 \%$ & $0 \%$ \\
\hline $75 \%$ & $25 \%$ \\
\hline $50 \%$ & $50 \%$ \\
\hline $25 \%$ & $75 \%$ \\
\hline $0 \%$ & $100 \%$ \\
\hline
\end{tabular}

After 40 days percentage of seed germination and germination period were estimated. An emerged radicle was the criterion for germination (Côme, 1982). and the growth of the seedlings was laboratory or greenhouse conditions.

Effect of season on seed germination: Thirty jojoba seeds were sown in plastic pots containing two $\mathrm{kg}$ of soil containing 1 and 1 , sand and clay soil, respectively. After 40 days percentage of seed germination and germination period were estimated.

\section{Effect of temperature on seed germination:}

Jojoba seeds were grown on cotton in glass jars contained $50 \mathrm{ml}$ Hogland solution and incubated at $30^{\circ} \mathrm{C}, 40^{\circ} \mathrm{C}$, and room temperature (maximum $18^{\circ} \mathrm{C}$ ). Germination frequency, length of roots, length of shoots and number of leaves per shoot were determined after four, nine, and 21 days of seedling.

\section{Effect of $\mathrm{NaCl}$ on seed germination:}

Under sterilized condition, Jojoba seeds were grown on cotton in glass jars contained $50 \mathrm{ml}$ of Hogland solution supplemented with several concentrations of $\mathrm{NaCl}(0,0.5$, $1,2,3,4 \mathrm{~g} / \mathrm{l})$. Jars were incubated at $30^{\circ} \mathrm{C}$. Germination frequency, length of roots, length of shoots and number of leaves per shoot were determined after four, nine, and twenty one days of seedling.

\section{Effect of mannitol on seed germination:}

Jojoba seeds were flooded on cotton layer in sterilized glass jars contained $50 \mathrm{ml}$ Hogland solution supplemented with several concentrations of mannitol $(0,0.5,1,2,3,4$ $\mathrm{g} / \mathrm{l})$. Jars were incubated at $30^{\circ} \mathrm{C}$. Germination frequency, length of roots, 
length of shoots and number of leaves per shoot were determined after four, nine, and twenty one days of seedling. In addition, jojoba seeds were placed on three cotton layers wetted with $50 \mathrm{ml}$ and containing different concentration of mannitol. The percentage of seed germination was determined in 40 days.

\section{Results and discussion:}

The used jojoba seeds were usually smooth, brown to black in colour, their dimensions are 8-17 $\mathrm{mm}$ in length and 5$11 \mathrm{~mm}$ in cross-section. One hundred seed weight can vary from $61-157.8 \mathrm{gm} / 100$ seed. Positive correlation was detected between seed size and oil content but the quality of the oil was exhibited very little variation regardless of the geographic origin of the seed (Yermanos, 1979). As was reported previously, the seeds contain little or no endosperm and consist mainly of the undifferentiated tissue of the cotyledons (Weiss, 1983). In this work, seeds were obtained after two months of harvesting date and they showed germination when they were subjected for suitable condition for seed germination. They were readily germinated in sandy or clay soil or in mixture from them under wide range of temperature from $18-40{ }^{\circ} \mathrm{C}$, it was in accordance with others studies (Gentry, 1958; Yermanos, 1982).

Data in this work (Table 1) indicated that sandy soil is the most suitable soil for seed germination of jojoba plant, where it is expressed the highest percentage of germinated seeds in short time. Therefore, our study indicates that jojoba is suitable plant for cultivation of the Egyptian marginal soils, in the desert area, where the plant can grow in sandy soil of marginal fertility and needs little water. It withstands salinity and it does not seem to need fertilizers or other polluting chemical treatments. Consequently, jojoba can be generally cultivated in well-drained, coarse, desert soils, where the soil is composed of sandy alluviums and mixtures of gravels and clays derived from such igneous materials as granitics and volcanics. For all of the previous reasons, jojoba is recommended for cultivation in Egyptian desert.

\begin{tabular}{|c|c|c|c|}
\hline \multicolumn{2}{|c|}{ Soil structure } & \multirow{2}{*}{$\begin{array}{c}\text { Percentage } \\
\text { of seed } \\
\text { germination } \\
(\%)\end{array}$} & \multirow{2}{*}{$\begin{array}{c}\text { Germinat } \\
\text { ion } \\
\text { period } \\
\text { (day) }\end{array}$} \\
\hline $\begin{array}{l}\text { Sand } \\
\text { y soil }\end{array}$ & $\begin{array}{c}\text { Clay } \\
\text { soil }\end{array}$ & & \\
\hline $100 \%$ & $0 \%$ & 75.0 & 13 \\
\hline $75 \%$ & $25 \%$ & 65.0 & $15^{*}$ \\
\hline $50 \%$ & $50 \%$ & 62.5 & $17 *$ \\
\hline $25 \%$ & $75 \%$ & 55.0 & $21^{*}$ \\
\hline $0 \%$ & $100 \%$ & 45.0 & $23 *$ \\
\hline
\end{tabular}

Table 1. Effect of soil type on percentage of seed germination and germination period.

* Means significantly different (t-test) from jojoba seeds cultured on Hogland solution at $30^{\circ} \mathrm{C}$ at $\mathrm{P}<0.05$.

Temperature may be the most critical factor in growing jojoba. Jojoba is living in the bright desert sun and tolerates the extreme daily fluctuations of temperature which commonly range through $-1{ }^{\circ} \mathrm{C}$ during the morning to daily extremes of $46{ }^{\circ} \mathrm{C}$ (shade readings). In our work, increase of temperature stimulated seed germination, shortened the time needed for emergence of radical (Table 2).

\begin{tabular}{|c|c|c|c|c|c|}
\hline $\begin{array}{c}\text { Age of } \\
\text { seedling }\end{array}$ & $\begin{array}{c}\text { Temperature of } \\
\text { incubation }\end{array}$ & $\begin{array}{c}\text { Seed germination } \\
\text { freq. }\end{array}$ & $\begin{array}{c}\text { Length of } \\
\text { root }\end{array}$ & $\begin{array}{c}\text { Shoot } \\
\text { freq. }(\text { co) }\end{array}$ & $\begin{array}{c}\text { Length } \\
\text { of shoot }\end{array}$ \\
\hline 3 days & $30^{\circ} \mathrm{C}$ & 61 & 0.26 & --- & --- \\
\hline 5 days & Room temperature & $55^{*}$ & 0.2 & --- & --- \\
\hline 7 days & $30^{\circ} \mathrm{C}$ & 72 & 0.4 & --- & --- \\
\cline { 2 - 6 } & Room temperature & 55 & 0.53 & --- & --- \\
\hline \multirow{2}{*}{15 days } & Room temperature & 55 & 2 & 33 & 1.5 \\
\cline { 2 - 6 } & $30^{\circ} \mathrm{C}$ & 72 & 7 & 66 & 0.8 \\
\hline
\end{tabular}

Table 2. Effect of temperatures on seed germination frequency.

* Means significantly different (t-test) from jojoba seeds cultured on Hogland solution at $30^{\circ} \mathrm{C}$ at $\mathrm{P}<0.05$.

Seed germination was influenced by temperature of the seasons. Seed germination in summer was higher than winter (Table 3). Summer was the best season for seed germination it may be due to the highest temperature degree. Also, the shortest time of seed germination was detected when the seeds were subjected for the highest temperature in summer. Seedlings are more sensitive than mature 
tree (Weiss, 1983). While seeding is sensitive to light frosts of -1 or $-2^{\circ} \mathrm{C}$ below freezing, mature shrubs are known to tolerate temperatures as low as $-9{ }^{\circ} \mathrm{C}$. When temperatures reach $5^{\circ} \mathrm{C}$ flowers and terminal portions of young branches of most jojoba plants are damaged. Wild jojoba plants can withstand very high temperature, cultivated cultivars showed maximum growth between $27-36{ }^{\circ} \mathrm{C}$, but. Above $50{ }^{\circ} \mathrm{C}$, the vegetative growth is suppressed, although not lethal (Weiss, 1983).

\begin{tabular}{|l|l|l|l|l|}
\hline \multirow{2}{*}{ Parameter } & \multicolumn{3}{|l|}{ Season } & \multicolumn{3}{|l|}{} \\
\cline { 2 - 5 } & Summer & Autumn & Winter & Spring \\
\hline Percentage of seed germination & $77 \pm 3.81$ & $63 \pm 2.00$ & $58 \pm 3.81$ & $73 \pm 2.50$ \\
\hline Germination period / day & $13 \pm 1.00$ & $17 \pm 1.00$ & $26 \pm 2.00$ & $17 \pm 1.52$ \\
\hline
\end{tabular}

Table 3. Effect of seasons on percentage of seed germination and germination period.

Under germination condition, the number of germinated jojoba seeds increased with time (Table 4, 5 and 6). In four days, salinity delayed seed germination of jojoba seed. While, $61 \%$ of seeds showed seed germination on $\mathrm{NaCl}$ free medium, $57 \%$ of seeds showed seed germination under the influence of $0.5 \mathrm{gm} / 1 \mathrm{NaCl}$ (Table 4). With time on germination medium, salinity stimulated seed germination (Table 5 and 6) especially, when the seeds were subjected for germination in the presence of relatively low concentration of $\mathrm{NaCl}(0.5-3 \mathrm{gm} / \mathrm{l})$. In this work, the negative effect of $\mathrm{NaCl}$ on seed germination was detected when the seeds were subjected for $4 \mathrm{gm} / \mathrm{l} \mathrm{NaCl}$. While jojoba is known as salt tolerant species (Jensen and Salisbury, 1988; Benzioni et al., 1992), salt damage can occur and differences in response among clones had been observed (Rasoolzadegan et al., 1980; Benzioni et al., 1992). indicating the possibility of developing clones with increased levels of salt resistance or tolerance.

Relatively low concentration of $\mathrm{NaCl}(0.5-$ $3 \mathrm{gm} / \mathrm{l}$ ) stimulated seedling growth and resulted in the formation of higher fresh mass than control. On the other hand, germination of seeds on medium containing $4 \mathrm{gm} / \mathrm{l} \mathrm{NaCl}$ retarded seedling growth with complete avoidance of shoots (Table 5 and 6). Elongation and thickening of stems (Bartolini et al., 1991). the total leaf area and leaf size (Bartolini et al., 1991). shoot and leaf expansion, number of leaves and flowers were reduced in response to increased levels of salinity (Rasoolzadegan et al., 1980; Benzioni et al., 1992). Increasing in leaf thickness was also reported when jojba plants were subjected to salt stress (Sa'nchez-Blanco et al., 1991).

\begin{tabular}{|c|c|c|}
\hline $\begin{array}{c}\text { Conc. of } \\
\text { NaCl (g/l) }\end{array}$ & $\begin{array}{c}\text { Germination } \\
\text { freq. (\%) }\end{array}$ & DRS \\
\hline Control & 61 & 0.27 \\
\hline 0.5 & $56.6^{*}$ & 0.17 \\
\hline 1 & $38^{*}$ & 0.13 \\
\hline 2 & $55.4^{*}$ & 0.6 \\
\hline 3 & $44^{*}$ & 0.1 \\
\hline 4 & $34.3^{*}$ & 0.1 \\
\hline
\end{tabular}

Table 4. Effect of $\mathrm{NaCl}$ on seed germination after four days under germination condition.

* Means significantly different (t-test) from jojoba seeds cultured on hogland solution without salt at $\mathrm{P}<0.05$.

Increase the concentration of $\mathrm{NaCl}$ over 3 $\mathrm{gm} / 1$ resulted in inhibition of seed germination as well as radicle growth (Table 5). Plumules were completely suppressed when $4 \mathrm{gm} / \mathrm{l} \mathrm{NaCl}$ were used. These results were in agreement with previous report (Berrichi et al., 2010). They were found that $5 \mathrm{~g} / \mathrm{l}$ of $\mathrm{NaCl}$ inhibited completely the emergence of plumules and, $3 \mathrm{~g} / \mathrm{l}$ of $\mathrm{NaCl}$ marked the start of negative effect on the growth jojoba seedlings.

\begin{tabular}{|c|c|c|c|c|}
\hline $\begin{array}{c}\text { Conc. of } \\
\text { NaCl } \mathbf{( g / l )}\end{array}$ & $\begin{array}{c}\text { Germination } \\
\text { freq. }(\mathbf{c})\end{array}$ & $\begin{array}{c}\text { Length of root } \\
(\mathbf{c m})\end{array}$ & $\begin{array}{c}\text { Shoot freq. } \\
(\mathbf{c})\end{array}$ & $\begin{array}{c}\text { Length of shoot } \\
(\mathbf{c m})\end{array}$ \\
\hline Control & 66 & 1.7 & 16 & 0.5 \\
\hline 0.5 & $61^{*}$ & 5.3 & 16 & 0.3 \\
\hline 1 & $66^{*}$ & 3 & 16 & 0.4 \\
\hline 2 & 83 & 11 & $33^{*}$ & 0.4 \\
\hline 3 & 75 & 7.25 & $33^{*}$ & 0.5 \\
\hline 4 & $41^{*}$ & $0.23^{*}$ & --- & --- \\
\hline
\end{tabular}

Table 5. Effect of $\mathrm{NaCl}$ on seed germination after nine days under germination condition. 
* Means significantly different (t-test) from jojoba seeds cultured on Hogland solution without salt at $\mathrm{P}<0.05$.

Relatively low concentration of $\mathrm{NaCl}$ resulted in enhancement of seedling growth up to $3 \mathrm{gm} / \mathrm{l} \mathrm{NaCl}$ (Table 6). The data also indicated that $4 \mathrm{gm} / \mathrm{l}$ of $\mathrm{NaCl}$ resulted in decreasing the radical length and inhibition of plumule formation. Botti et al., (1998) reported that jojoba plants grown under high salt levels did not show much difference from those grown under non-saline conditions for most of the morphological and anatomical parameters such as number and size of stomata, density of trichomes, leaf size, branching characteristics and stem diameter. On the other side they found that leaf and cuticle thickness showed a high tendency to increase under saline conditions.

\begin{tabular}{|c|c|c|c|c|c|c|}
\hline $\begin{array}{c}\text { Conc. of } \\
\text { NaCl (g/l) }\end{array}$ & $\begin{array}{c}\text { Germination } \\
\text { freq. (\%) }\end{array}$ & $\begin{array}{c}\text { Length of } \\
\text { root }(\mathbf{c m})\end{array}$ & $\begin{array}{c}\text { Plumule } \\
\text { formation } \\
\text { freq. (\%) }\end{array}$ & $\begin{array}{c}\text { Length of } \\
\text { shoot }(\mathbf{c m})\end{array}$ & $\begin{array}{c}\text { No. of } \\
\text { leaves per } \\
\text { shoot }\end{array}$ & $\begin{array}{c}\text { No. of } \\
\text { shoots } \\
\text { per seed }\end{array}$ \\
\hline Control & 69 & 2 & 33.3 & 0.8 & 2 & 1 \\
\hline 0.5 & $66.6^{*}$ & 6.66 & 50 & 1 & 2 & 1 \\
\hline 1 & $66.6^{*}$ & $3 *$ & 50 & 1 & 3 & 1 \\
\hline 2 & $83^{*}$ & 15.3 & 42.2 & 4 & 6 & 1 \\
\hline 3 & 83.3 & 14.3 & $33^{*}$ & 2.3 & 4 & 1 \\
\hline 4 & $50^{*}$ & $0.73^{*}$ & --- & --- & --- & -- \\
\hline
\end{tabular}

Table 6. Effect of $\mathrm{NaCl}$ on seed germination after fifteen days under germination condition.

* Means significantly different (t-test) from jojoba seeds cultured on Hogland solution without salt at $\mathrm{P}<0.05$.

Mannitol as same as $\mathrm{NaCl}$ delayed seed germination of jojoba plant (Table 7). Application of 2 or $3 \mathrm{gm} / 1$ mannitol in germination medium improved the seed germination. Comparison between the effect of $\mathrm{NaCl}$ and mannitol indicated that incorporation of these both factors in relatively low concentration improved seed germination.

\begin{tabular}{|c|c|c|}
\hline $\begin{array}{c}\text { Conc. of } \\
\text { mannitol }(\mathbf{g} / \mathbf{l})\end{array}$ & $\begin{array}{c}\text { Germination } \\
\text { freq. (\%) }\end{array}$ & $\begin{array}{c}\text { Length of } \\
\text { roots }(\mathbf{c m})\end{array}$ \\
\hline Control & 61 & 0.27 \\
\hline 0.5 & $46^{*}$ & $0.1^{*}$ \\
\hline 1 & $55^{*}$ & 1.8 \\
\hline 2 & $46^{*}$ & $0.46^{*}$ \\
\hline 3 & $33^{*}$ & $0.16^{*}$ \\
\hline 4 & $27^{*}$ & $0.1^{*}$ \\
\hline
\end{tabular}

Table 7. Effect of mannitol on seed germination after four days under germination condition.
* Means significantly different (t-test) from jojoba seeds cultured on Hogland solution without mannitol at $\mathrm{P}<0.05$.

The data in this work indicated that the emergence of plumules were commenced after four days of subjecting the seeds for germination conditions (Table 8 and 9). The commencement of plumules was depend on the concentration of mannitol in the germination medium. While relatively low concentrations of mannitol $(1-3 \mathrm{gm} / \mathrm{l})$ stimulate plumule formation, $4 \mathrm{gm} / \mathrm{l}$ mannitol inhibit completely the emergence of seed plumule. The same results were obtained when $4 \mathrm{gm} / \mathrm{l} \mathrm{NaCl}$ were used (Table 6).

\begin{tabular}{|c|c|c|c|c|}
\hline $\begin{array}{c}\text { Conc. of } \\
\text { mannitol } \\
(\mathbf{g} / \mathbf{l})\end{array}$ & $\begin{array}{c}\text { Germination } \\
\text { freq. (\%) }\end{array}$ & $\begin{array}{c}\text { Length of } \\
\text { roots }(\mathbf{c m})\end{array}$ & $\begin{array}{c}\text { Plumule } \\
\text { freq. (\%) }\end{array}$ & $\begin{array}{c}\text { Length of } \\
\text { shoots (cm) }\end{array}$ \\
\hline Control & 66 & 1.7 & 16 & 0.5 \\
\hline 0.5 & $55.5^{*}$ & $1.15^{*}$ & 16 & 0.5 \\
\hline 1 & $55^{*}$ & 8.5 & 50 & 0.3 \\
\hline 2 & $66^{*}$ & 7 & 33 & 0.2 \\
\hline 3 & 83 & 3.3 & 25 & 1 \\
\hline 4 & $50^{*}$ & $0.5^{*}$ & --- & -- \\
\hline
\end{tabular}

Table 8. Effect of mannitol on seed germination after nine days under germination condition. 
* Means significantly different (t-test) from jojoba seeds cultured on Hogland solution without mannitol at $\mathrm{P}<0.05$.

Plumule formation were delayed under the influence of $4 \mathrm{gm} / \mathrm{l}$ mannitol where it was only commenced in two weeks (Table 9). On the other hand, in two weeks, $4 \mathrm{gm} / 1$ mannitol stimulated the radical length in comparison to that of control. These data indicated that mannitol in concentration between 1 and $3 \mathrm{~m} / \mathrm{l}$ stimulated both shoot length and the number of shoots per seed.

\begin{tabular}{|c|c|c|c|c|c|c|}
\hline $\begin{array}{c}\text { Conc. of } \\
\text { mannitol } \\
(\mathbf{g} / \mathbf{l})\end{array}$ & $\begin{array}{c}\text { Germination } \\
\text { freq. (\%) }\end{array}$ & $\begin{array}{c}\text { Length of } \\
\text { roots }(\mathbf{c m})\end{array}$ & $\begin{array}{c}\text { Plumule } \\
\text { freq. (\%) }\end{array}$ & $\begin{array}{c}\text { Length of } \\
\text { shoots (cm) }\end{array}$ & $\begin{array}{c}\text { No. of } \\
\text { leaves per } \\
\text { shoot }\end{array}$ & $\begin{array}{c}\text { No. of } \\
\text { shoots } \\
\text { per seed }\end{array}$ \\
\hline Control & 66 & 2 & 33 & 0.8 & 2 & 1 \\
\hline 0.5 & $55.5^{*}$ & 2 & 33 & 0.8 & 2 & 1 \\
\hline 1 & $58^{*}$ & 14.6 & 50 & 3.16 & 2 & 2 \\
\hline 2 & 83 & 9 & 33 & 1.1 & 2 & 1 \\
\hline 3 & 83 & 7.66 & 83 & 1.81 .8 & 2 & 3 \\
\hline 4 & $50^{*}$ & 5.7 & $30^{*}$ & 0.66 & --- & 1 \\
\hline
\end{tabular}

Table 9. Effect of mannitol on seed germination of seeds placed on one layer of cotton flooded with Hogland solution for fifteen days.

* Means significantly different (t-test) from jojoba seeds cultured on Hogland solution without mannitol at $\mathrm{P}<0.05$.

Placing jojoba seeds on three cotton layers just wetted by germination medium created suitable condition for seed germination although the presence of high concentration of mannitol. Under these conditions, jojoba seeds were able to germinate and form plumule up to $100 \mathrm{gm} /$ mannitol. Comparision between data in tables 9 and 10 indicated that seed germination was strongly affected by the presence of high water content in germination medium. It was expected since the plant strongly tolerates drought condition but it is sensitive for frost and water flooding. Consequently, jojoba has recently established as a crop in many arid and semi-arid regions of the world (Brown et al., 1996), especially around the Mediterranean basin (Benzioni and Dunstone, 1986; Mills et al., 1997) because it is drought and salt tolerant plant species.

\begin{tabular}{|l|c|c|c|c|c|c|c|c|c|c|c|c|}
\hline \multirow{2}{*}{ Treatment } & \multicolumn{10}{|c|}{ Mannitol concentration (gm/l) } \\
\cline { 2 - 13 } & 0 & 10 & 20 & 30 & 40 & 50 & 60 & 70 & 80 & 90 & 100 & 110 \\
\hline $\begin{array}{l}\text { Percentage of seeds } \\
\text { cultured (\%) }\end{array}$ & 86 & 96 & 86 & 80 & $76^{*}$ & $63^{*}$ & $60^{*}$ & $56^{*}$ & $46^{*}$ & $43^{*}$ & $36^{*}$ & $20^{*}$ \\
\hline $\begin{array}{l}\text { Germination period } \\
\text { (day) }\end{array}$ & 8 & 7 & 9 & 11 & 11 & 13 & 15 & 16 & 17 & 19 & 21 & 25 \\
\hline $\begin{array}{l}\text { N .of shoot } \\
\text { formation }\end{array}$ & 18 & $27^{*}$ & $12^{*}$ & $10^{*}$ & $8^{*}$ & $7^{*}$ & $6^{*}$ & $5^{*}$ & $3^{*}$ & $2^{*}$ & $1^{*}$ & 0 \\
\hline
\end{tabular}

Table 10. Effect of mannitol on seed germination of seeds placed on three layers of cotton and witted with distilled water solution for fifteen days.

* Means significantly different (t-test) from jojoba seeds cultured on distilled water without mannitol at $\mathrm{P}<0.05$.

The data of his work indicated that jojoba is the most suitable plant for the Egyptian conditions especially in desert area. Under Egyptian condition, jojoba maximally utilizes 50-70 liters of water weekly in summer and 10-30 liters in winter but when it irrigated by flooding, 12-15 irrigation times per year is needed. Mature shrubs characterize by their strong ability to survive without irrigation for long time where they can survive for a whole year without watering. Jojoba can also tolerate up to 3,000 p.p.m. without any impact to the yield. Therefore, Jojoba is considered one of the most practical and scientific solutions for desert plantation in Egypt.

\section{References:}

Bartolini, G., Mazuelos, C., Troncoso, A., (1991). Influence of $\mathrm{Na} 2 \mathrm{SO} 4$ and $\mathrm{NaCl}$ salts on survival, growth and mineral composition of young olive plants in inert sand culture. Adv. Hortic. Sci. 5, 73-76.

Benzioni, A., Nerd, A., Rosengartner, Y., Mills, D. (1992). Effect of $\mathrm{NaCl}$ salinity on growth and development of jojoba clones I. 
Young plants. J. Plant Physiol. 139, 731736.

Benzioni, A, Shiloh, E., Ventura, M. (1999). Yield parameters in young jojoba plants and their relation to actual yield in later years Industrial Crops and Products 10: 85-95.

Berrichi, A., Tazi, R., Bellirou, A., Kouddane, N., Bouali A. (2010). Role of salt stress on seed germination and growth of jojoba plant Simmondsia chinensis (Link) Schneider. IUFS J Biol 69:33-39

Botti, C., Palzkill, D., Munoz, D., Prat, L. (1998). a. Morphological and anatomical characterization of six jojoba clones at saline and non-saline sites. Ind. Crops Prod. 9, 53-62.

Brown, J.H., Palzkill, D., Whittaker, C., (1996). The jojoba industry 1994, a status and update. In: Princen, L.H., Rossi, C. (Eds.), Proc. of the Ninth International Conf. on Jojoba and Its Uses, and of the Third International Conf. on New Industrial Crops and Products, 25-30 September 1994, Catamarca, Argentina, pp. 150-154.

Côme, D. (1982). Germination. In: Mazliak P., ed. Croissance et développement. Physiologie végétale. II. Paris: Hermann, 129-225.

El Mogy, N.S. (1999). Egyptian Experience in Planting Jojoba Fourth International Water Technology Conference IWTC 99, Alexandria, Egypt 431.

Jensen, W.A., Salisbury, F.B. (1988). Botánica, 2nd ed. Libros McGraw-Hill de Me'xico, Me'xico, $722 \mathrm{pp}$.

Harsh, L.H., Tewari, J.C., Patwal, D.S. and Meena, G.L. (1987). Package of Practices for Cultivation of Jojoba (Simmondsia chinensis) in AridZone, Pp: 1-19. CAZRI, Jodhpur (India).

Mohasseb, A.H., Mohamed, K., El-Bahr, M.K., Adam, Z.M., Moursy, H.A. and Solliman,
M. (2009). In Vitro Clonal Propagation of Jojoba (Simmondsia Chinensis (Link) Schn.). Aus tralian Journal of Bas ic and Applied Sciences , 3: 3128-3136.

Rasoolzadegan, Y., Hogan, L., Palzkill, D.A. (1980). Response of jojoba to five levels of salinity. In: Puebla, M. (Ed.), Proc. of the IV International Conf. on Jojoba, 5-6 November 1980, Hermosillo, Sonora, Mexico, pp. 113- 120.

Roussos, P.A., Tolia-Marioli, A., Pontikis, C.A. and Kotsias, D. (1999). Rapid multiplication of Jojoba seedlings by in vitro culture. Plant Cell, Tissue and Organ Culture 57: 133-137.

Roussos, P.A., Tsantili, E., Pontikis, C.A. (2006). Responses of jojoba explants to different salinity levels during the proliferation stage in vitro Industrial Crops and Products 23: 65-72.

Sa'nchez-Blanco, M.J., Boları́n, M.C., Alarco’n, J.J., Torrecillas, A. (1991). Salinity effects on water relations in Lycopersicon esculentum and its wild salt-tolerant relative species L. pennelli. Physiol. Plant. 83, 269274.

Weiss, E.A. (1983). Crambe, niger and jojoba. In: Oilseed Crops. Longman, London, UK, pp. 507 - 527.

Yermanos, D.M. 1979. Jojoba - a crop whose time has come. California Agriculture (Jul Aug.), pp. 4 - 11.

Yermanos, D.M. (1982). Jojoba - A potentially valuable species in the control of desertification. Proceedings of the Conference on Alternative Strategies for Desert Development and Management, 31 May - 10 June 1977, United Nations Institute for Training and Research, Sacramento, California, USA. Agriculture Vol. 2, pp. 374 - 381.

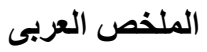

\section{إنبات بذور نبات الجوجويا تحت تأثير العديد من الظروف}

دلت النتائج أن نبات الجوجوبا هو الاختيار الأمثل لزراعة التربة الفقيرة للصحاري المصرية لمقدرة النبات علي الإنبات

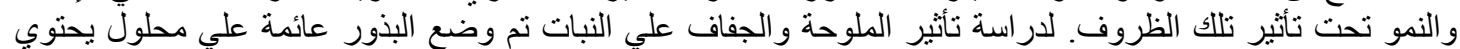

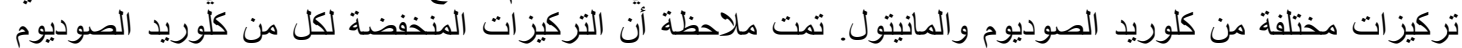

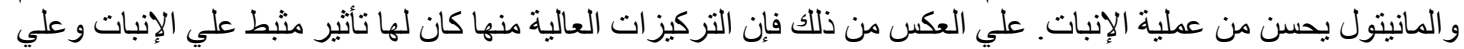

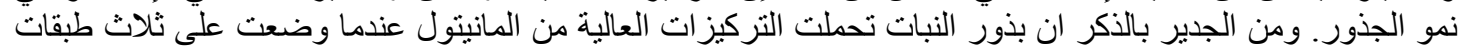

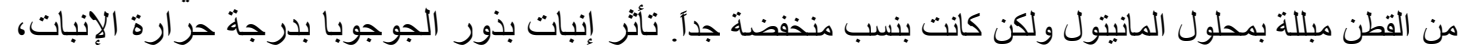

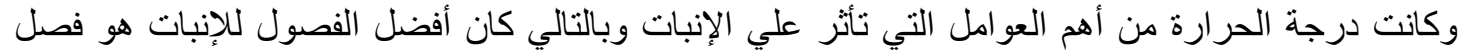
الصيف، أضف إلي ذلك أن تحضين البذور عند درجة حرارة ــ درجة مؤوية زادة من الإنبات ونمو البادر ات. 